Late Quaternary foraminiferal record in Murchisonfjorden, Nordaustlandet, Svalbard

Kubischta, Frauke

2010

Kubischta , F , Knudsen , K L , Kaakinen , A \& Salonen , V-P 2010 , ' Late Quaternary foraminiferal record in Murchisonfjorden, Nordaustlandet, Svalbard ' , Polar Research, vol. 29 , no. 3 , pp. 283-297 . https://doi.org/10.1111/j.1751-8369.2010.00173.x

http://hdl.handle.net/10138/162047

https://doi.org/10.1111/j.1751-8369.2010.00173.x

cc_by_nc

publishedVersion

Downloaded from Helda, University of Helsinki institutional repository.

This is an electronic reprint of the original article.

This reprint may differ from the original in pagination and typographic detail.

Please cite the original version. 


\title{
Late Quaternary foraminiferal record in Murchisonfjorden, Nordaustlandet, Svalbard
}

\author{
Frauke Kubischta, ${ }^{1}$ Karen Luise Knudsen, ${ }^{2}$ Anu Kaakinen ${ }^{1}$ \& Veli-Pekka Salonen ${ }^{1}$ \\ 1 Department of Geosciences and Geography, Division of Geology, University of Helsinki, Gustaf Hällströmin katu 2a, PO Box 64, Fl-00014 Helsinki, \\ Finland \\ 2 Department of Earth Sciences, Aarhus University, Høegh-Guldbergs Gade 2, DK-8000 Århus C, Denmark
}

\section{Keywords \\ Quaternary stratigraphy; benthic \\ foraminifera; palaeoenvironments; Arctic; Svalbard. \\ Correspondence \\ Frauke Kubischta, Department Geosciences and Geography, Division of Geology, University of Helsinki, Gustaf Hällströmin katu 2a, PO Box 64, Fl-00014 Helsinki, Finland. E-mail: frauke.kubischta@helsinki.fi}

doi:10.1111/j.1751-8369.2010.00173.x

\begin{abstract}
Benthic foraminiferal assemblages from Nordaustlandet, Svalbard, are described for the first time with the objective of reconstructing the palaeoenvironmental conditions in the area during the late Quaternary. Investigations were carried out on marine deposits exposed along the southern shores of Murchisonfjorden. Five foraminiferal assemblages (Al-A5), representing different palaeoenvironmental conditions, were identified from the marine intervals, i.e., the Cassidulina reniforme-Elphidium albiumbilicatum assemblage (Al) from the Early Weichselian, the Islandiella helenae-Cibicides lobatulus assemblage (A2) from the Early Weichselian, the Cibicides lobatulus-Cassidulina reniforme assemblage (A3) from marine isotope stage 3, the Elphidium albiumbilicatum assemblage (A4) from the early Holocene and the Astrononion gallowayi assemblage (A5) from the mid-Holocene. Assemblages Al-A5 are compared with modern and fossil Quaternary assemblages from Arctic regions. Particularly notable is the fact that a well-defined Middle Weichselian assemblage in Svalbard is described for the first time, i.e., the Cibicides lobatulusCassidulina reniforme assemblage. All the assemblages from Nordaustlandet represent glacier-distal, inner-shelf environments with an open connection to the ocean. The results reveal the occurrence of three marine intervals (ice-free periods) in the north-western part of Nordaustlandet during the Weichselian, as well as ice-free conditions during most of the Holocene. A comparison of the assemblages from Nordaustlandet with previously published foraminiferal zones from onshore sections elsewhere in Svalbard show some degree of similarity, but also show considerable variation in species compositions, presumably caused by local environmental differences.
\end{abstract}

Nordaustlandet is the north-easternmost island of the Svalbard archipelago $\left(76-81^{\circ} \mathrm{N}, 10-30^{\circ} \mathrm{E}\right.$; Fig. 1), separated from the main island, Spitsbergen, by Hinlopenstretet. Much of Nordaustlandet is covered by two large ice caps, Vestfonna and Austfonna, and only small areas along the northern, north-western and southern coasts are free of ice (Fig. 1). Rapid isostatic uplift after the last deglaciation has led to the exposure of marine deposits that are now accessible in a number of vertical coastal sections, a few metres high, containing rich biostratigraphical and sedimentological information (Blake 1961, 1981).

To complement previous studies on the stratigraphy of Quaternary sediments from around Svalbard by Lønne \&
Mangerud (1991), Mangerud \& Svendsen (1992), Andersen et al. (1996) and Houmark-Nielsen \& Funder (1999), Kaakinen et al. (2009) have performed sedimentological studies at a series of exposures in the south-eastern part of Murchisonfjorden, Nordaustlandet. They found that marine sands and gravels are interlayered with tills deriving from multiple glacier advances throughout the Weichselian. These marine sands and gravels were also found to contain pelecypod remains and foraminifera, but the faunal material in the sections was not investigated in any detail.

Overall, Quaternary research on Nordaustlandet has previously focused on glacial geology, geomorphology and palaeolimnological studies, rather than on 

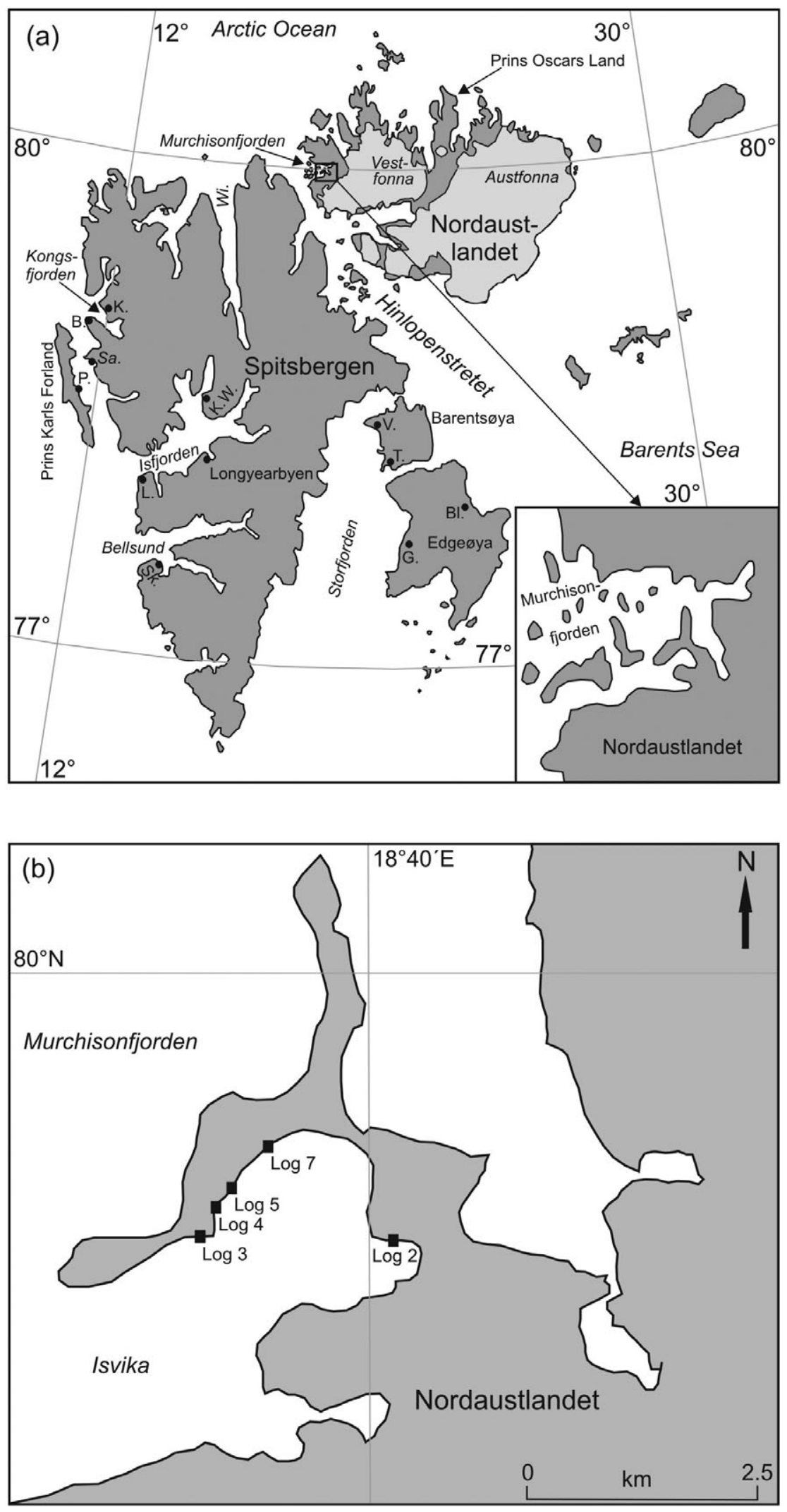

Fig. 1 (a) Location of the study area in Murchisonfjorden in the north-western part of Nordaustlandet, Svalbard, with an inserted close-up of the Murchisonfjorden area, and (b) the sections in Isvika. Abbreviations: B., Brøggerhalvøya; BI., Blåfjorddalen; G., Guldalen; K., Kongsfjordhallet; K.W., Kapp Wijk; L., Linnéelva; P., Poolepynten; Sa., Sarsbukta; Sk., Skilvika; T., Talavera; V., Visdalen; Wi., Wijdefjorden. 
biostratigraphy and sedimentology of the marine deposits. Donner \& West $(1957,1995)$ examined the Weichselian deglaciation and emergence history at Brageneset (Fig. 1), and reported observations on the glacial geology of Nordaustlandet. The ice-movement history of Nordaustlandet, including the radiocarbon age determination of raised beaches, land uplift, morphological investigations and climatic implications of the occurrence of Mytilus edulis, were studied by Blake (1961, 1962, 2006). In his $\mathrm{PhD}$ thesis, Blake (1962) even described reworked foraminifera within tills in the Murchisonfjorden area.

Hyvärinen (1969, 1970) established a pollen stratigraphy for the last 10000 years based on lake sediment records from Nordaustlandet and Spitsbergen. These studied cores also revealed marine strata with abundant benthic foraminifera, but Hyvärinen (1969) only mentioned three taxa, determined to genus level, from the marine interval. This points to a clear lack of knowledge of the marine biostratigraphy of the area.

Foraminiferal palaeoecological and stratigraphical studies have, however, previously been performed for several core records from fjords and the adjacent shelf areas in Svalbard (e.g., Svendsen et al. 1996; Wollenburg et al. 2001; Koç et al. 2002; Hald et al. 2004; Ślubowska et al. 2005; Korsun et al. 2006; Rasmussen et al. 2007; Ślubowska-Woldengen et al. 2007; Hald \& Korsun 2008; Majewski et al. 2009), as well as for raised marine deposits from coastal sections around the archipelago (e.g., Feyling-Hanssen 1965; Nagy 1984; Miller et al. 1989; Landvik et al. 1992; Lycke et al. 1992; Mangerud et al. 1992; Svendsen \& Mangerud 1992;
Ingólfsson et al. 1995; Bergsten et al. 1998; Mangerud et al. 1998).

The aim of this study is to examine the micropalaeontological record from some of the raised marine deposits in Murchisonfjorden, Nordaustlandet, and to use the benthic foraminifera to infer, on a relative and qualitative basis, the palaeoenvironmental conditions such as water temperature, salinity, water depth and current energy for the Late Quaternary in the area. This is achieved by a comparison with modern assemblage distributions of foraminifera, particularly in the Svalbard area, but also in adjacent Arctic regions such as northern Norway, northern Russia and Greenland. In addition, an attempt is made to correlate the different marine units in the coastal sections in Murchisonfjorden with similar deposits described from other onshore sections around the Svalbard archipelago.

\section{Late Quaternary sections in Murchisonfjorden}

The research material presented here was collected from a coastal area west of Vestfonna during a 3-week-long field campaign in July-August 2007. The seven sections, which were recently reported on by Kaakinen et al. (2009) are situated along the shores of Isvika on the southern side of Murchisonfjorden in Nordaustlandet, Svalbard (Fig. 1). Only five of these sections were used for optically stimulated luminescence (OSL) dating and for the present study (Fig. 2). Kaakinen et al. (2009) identified a total of 12 lithofacies units, and recognized evidence from three depositional sequences. Each sequence includes till unit(s) overlain by sorted marine

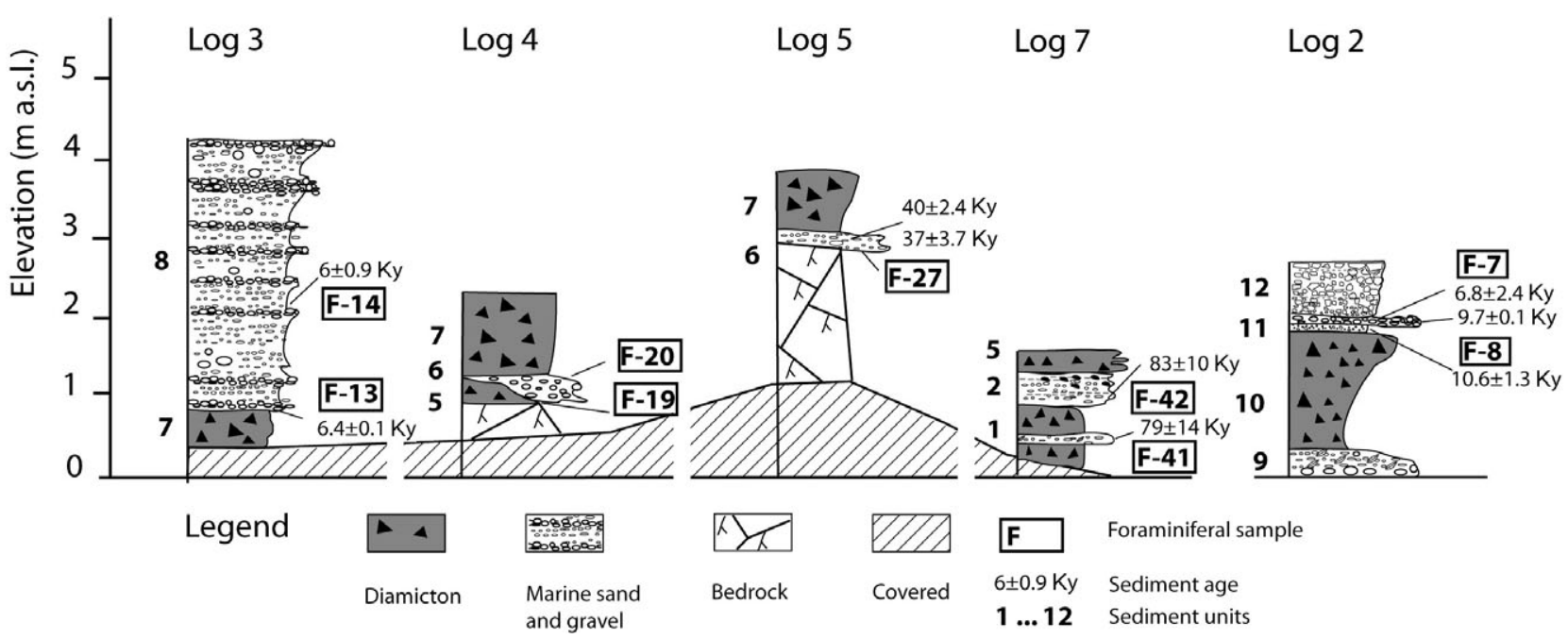

Fig. 2 Lithostratigraphical correlations of the sections in Isvika, Murchisonfjorden, with indication of sediment facies, unit numbers, foraminiferal sample locations and mean ages. Modified from Kaakinen et al. (2009). 
sands and gravels. The sedimentological analyses indicated that the tills were deposited as a result of lodgement, melt-out and deformation processes, whereas the raised marine strata were interpreted to represent upper shoreface, foreshore, and littoral gravels and beach deposits.

The ages of the deposits, which were constrained by OSL dating of well-bleached quartz grains and accelerator mass spectrometry (AMS) ${ }^{14} \mathrm{C}$ age determinations of shells, range from over $80 \mathrm{Ky}$ to around $6 \mathrm{Ky}$ (Kaakinen et al. 2009). Two samples gave ages within the time frame of the Phantomodden Interstadial, marine isotope stage (MIS) 5c-a (Mangerud et al. 1998), and one was dated to MIS 3 and correlated with the Kapp Ekholm Interstadial. Four age determinations cover the Holocene epoch, with the oldest results being close to the time of the deglaciation of the island, and two results representing the mid-Holocene.

The grain sizes of the marine strata ranges from clayey silt to gravel, and they contain a rich macro- and microfauna such as Mya truncata, Astarte sp., Hiatella arctica, Astarte borealis and Chlamys islandica, foraminifera and some ostracoda, although in varying states of preservation.

The younger shells are better preserved, less mechanically abraded and have been exposed less to calcareous dissolution than those in the older units. The relatively poor preservation of both macro- and microfossil shells in the older sediments is considered to be the result of overriding during subsequent glaciations, plus frost action and post-depositional solifluction, but the foraminiferal tests may also have been damaged further during the laboratory treatment (see below).

\section{Material and methods}

The nine samples that were available for this foraminiferal study were originally used to determine water contents of the sediment units, from which OSL dates were obtained (sediment units 1, 2, 6, 8, 11 and 12; no OSL dates were carried out from units 5, 7, 9 and 10) (Kaakinen et al. 2009). As a result of the required laboratory treatment for water content determination (heating to $105^{\circ} \mathrm{C}$ for several hours), some specimens, particularly small or thin-shelled tests and agglutinated tests, may have been damaged. Yet, we consider the material to be sufficient for this first overview of foraminiferal assemblages in the Quaternary deposits of Nordaustlandet.

After drying (dry weights vary from 40.2 to $49.6 \mathrm{~g}$ ), the samples for foraminiferal analysis were wet-sieved through a stack of sieves with mesh sizes of 1.000, 0.250, 0.125 and $0.063 \mathrm{~mm}$. The fractions were dried on the sieves and then stored in glass vials for future analysis. For foraminiferal analysis, the $0.125-\mathrm{mm}$ fraction was concentrated by soap flotation to avoid the excessive use of chemicals, and was again dried in an oven at $50^{\circ} \mathrm{C}$. In two samples (samples 13 and 41), the foraminiferal shells were still mixed with sand grains after flotation with soap. Therefore, the usual heavy liquid method $\left(\mathrm{C}_{2} \mathrm{Cl}_{4}\right)$ was subsequently applied for the preparation of these, following the method described by Feyling-Hanssen et al. (1971) and Knudsen (1998).

Of the nine samples that were available for foraminiferal analysis (Fig. 2), one did not contain any foraminifera (sample 20), and one contained only two specimens of Cibicides lobatulus (sample 19; Table 1). These two samples are not further discussed. In samples with low abundances of foraminifera (samples 14, 7, 8, 27, 42 and 41), all the specimens were determined and picked, but only approximately one-eighth of sample 13 was counted. A total of 21 calcareous benthic taxa were identified. One sample (14) contained a single planktonic specimen. Agglutinated species are generally not preserved in this kind of material, and only a few specimens were found.

The counts and the original references for all the species and species groups are listed in Table 1 . The number of specimens per $100 \mathrm{~g}$ of dry sediment is generally low, ranging from ca. 75 to 14200 in the fossiliferous samples. A faunal diversity index, defined by Walton (1964) as the number of ranked species that accounts for $95 \%$ of a counted assemblage, was applied to the assemblages. This faunal diversity index and the number of benthic calcareous species have values of 6-10 and 7-15, respectively.

Elphidium albiumbilicatum and Elphidium hallandense are grouped as Elphidium albiumbilicatum/hallandense in one of the samples (sample 13; Fig. 3; Table 1), because the occurrences of transition forms between the two species made a separation difficult. Both species indicate shallow and/or brackish conditions, but as Elphidium hallandense is a High-Arctic species, whereas Elphidium albiumbilicatum often occurs in sub-Arctic waters, a possible climatic indication may be lost by this grouping (see the discussion in Knudsen 1978). However, the climatic indication of Elphidium albiumbilicatum is still relatively uncertain, as discussed by Hansen \& Knudsen (1995).

Because of the poor preservation state, some species of the genus Elphidium have also been grouped (as Elphidium spp.). This group is suggested primarily to include Elphidium excavatum f. clavata, Elphidium albiumbilicatum and Elphidium hallandense. Elphidium spp. is a shallow-water group that is generally tolerant to changes in salinity (e.g., Murray 1991, 2006). Species within the family Polymorphinidae are also grouped. Agglutinated 
Table 1 Foraminiferal counts and faunal characteristics of eight samples from Isvika, Murchisonfjorden, Svalbard. The original references and descriptions of the taxa are reported in Ellis \& Messina (1949, and supplements up to 2007). For logs and sedimentary units, see Figs. 2 and 3. Agglutinated and planktonic foraminifera are excluded from the percentage calculations of Fig. 3.

\begin{tabular}{|c|c|c|c|c|c|c|c|c|}
\hline Sample no. & 19 & 14 & 13 & 7 & 8 & 27 & 42 & 41 \\
\hline Log/unit & 4 & $3 / 8$ & $3 / 8$ & $2 / 12$ & $2 / 11$ & $5 / 6$ & $7 / 2$ & $7 / 1$ \\
\hline Sample weight in $\mathrm{g}$ (dry) & 45 & 40 & 41 & 46 & 44 & 46 & 50 & 45 \\
\hline Specimens counted & 2 & 224 & 734 & 237 & 320 & 117 & 34 & 825 \\
\hline Specimens per $100 \mathrm{~g}$ of sediment & & 560 & 1780 & 510 & 720 & 250 & 75 & 14200 \\
\hline Faunal diversity (Walton 1964) & & 10 & 10 & 6 & 8 & 8 & & 7 \\
\hline No. of species & 1 & 13 & 15 & 12 & 14 & 11 & 7 & 14 \\
\hline Assemblage no. & & A5 & A5 & A4 & A4 & A3 & A2 & A1 \\
\hline Astrononion gallowayi Loeblich \& Tappan, 1953 & & 38 & 342 & 21 & 44 & 6 & & 1 \\
\hline Buccella frigida (Cushman, 1922) & & 12 & 13 & 3 & 3 & 3 & 2 & 91 \\
\hline Cassidulina reniforme Nørvang, 1945 & & 31 & 150 & 35 & 43 & 25 & 1 & 314 \\
\hline Cibicides lobatulus (Walker \& Jacob, 1798) & 2 & 36 & 28 & 54 & 38 & 37 & 10 & 5 \\
\hline Elphidium albiumbilicatum (Weiss, 1954) & & 20 & 47 & 70 & 108 & & & 177 \\
\hline Elphidium albiumbilicatum/hallandense & & & 17 & & & & & \\
\hline Elphidium excavatum (Terquem, 1875) & & 28 & 22 & 33 & 29 & 14 & 4 & 65 \\
\hline Elphidium hallandense Brotzen, 1943 & & 18 & 29 & & 22 & 3 & & 9 \\
\hline Elphidium incertum Williamson, 1858 & & & 1 & & & & & \\
\hline Elphidium magellanicum Heron-Allen \& Earland, 1932 & & & & & 1 & & & \\
\hline Elphidium spp. & & 7 & 12 & 6 & 3 & 5 & 2 & 7 \\
\hline Fissurina spp. & & & 7 & & & & & 1 \\
\hline Haynesina orbiculare (Brady, 1881) & & 5 & 42 & 1 & & 2 & 1 & 15 \\
\hline Islandiella helenae Feyling-Hanssen \& Buzas, 1976 & & 13 & & 9 & 3 & 17 & 14 & 114 \\
\hline Lagena spp. & & & & & & & & 2 \\
\hline Nonionellina labradorica (Dawson, 1860) & & 5 & 12 & 22 & 16 & 4 & & 9 \\
\hline Nonion matchigaricus Voloshinova, 1952 & & & & & 6 & & & \\
\hline Patellina corrugata Williamson, 1858 & & 1 & 5 & & & & & \\
\hline Stainforthia loeblichi (Feyling-Hanssen, 1954) & & & & 2 & 3 & & & \\
\hline Trifarina fluens (Todd, 1947) & & & & & & 1 & & \\
\hline Polymorphinidae & & 9 & 3 & 2 & 1 & & & 9 \\
\hline Indeterminate, calcareous taxa & & 1 & 4 & & & & & 6 \\
\hline Agglutinated species & & 4 & & 1 & 7 & & & \\
\hline Planktonic species & & 1 & & & & & & \\
\hline
\end{tabular}

and planktonic taxa are not included in the percentage calculations of Fig. 3.

\section{Foraminiferal assemblages and palaeoenvironments}

Five foraminiferal assemblage zones (Al-A5) were identified on the basis of the faunal compositions in the material from Nordaustlandet, according to the definition by Salvador (1994). Assemblage zones Al-A3 are represented by only one sample each, whereas assemblage zones A4 and A5 are comprised of two samples each. The percentage distribution of foraminiferal taxa in assemblage zones Al-A5 is shown in Fig. 3 together with a composite lithostratigraphical $\log$, the facies sequences, the sedimentary units and the mean age of each sample (after Kaakinen et al. 2009). A description of the foraminiferal contents of each assemblage zone is given below, together with a palaeoenvironmental interpretation, which is summarized in Table 2. The lithological descriptions and age determinations are based on earlier investigations in the area (Kaakinen et al. 2009).

\section{Assemblage zone A1: Cassidulina reniforme- Elphidium albiumbilicatum assemblage (sample 41)}

Description. The sediment consists of well-sorted fine to medium sand with both whole and broken pelecypod shells, mainly of Mya truncata. The sample contains an extremely rich foraminiferal assemblage with a faunal diversity of 7 , and is dominated by Cassidulina reniforme and Elphidium albiumbilicatum, with Buccella frigida and Islandiella helenae as the second most abundant species. Elphidium excavatum (as forma clavata; see FeylingHanssen 1972), Haynesina orbiculare, Cibicides lobatulus, Nonionellina labradorica and Elphidium hallandense also play an important role (Fig. 3). 


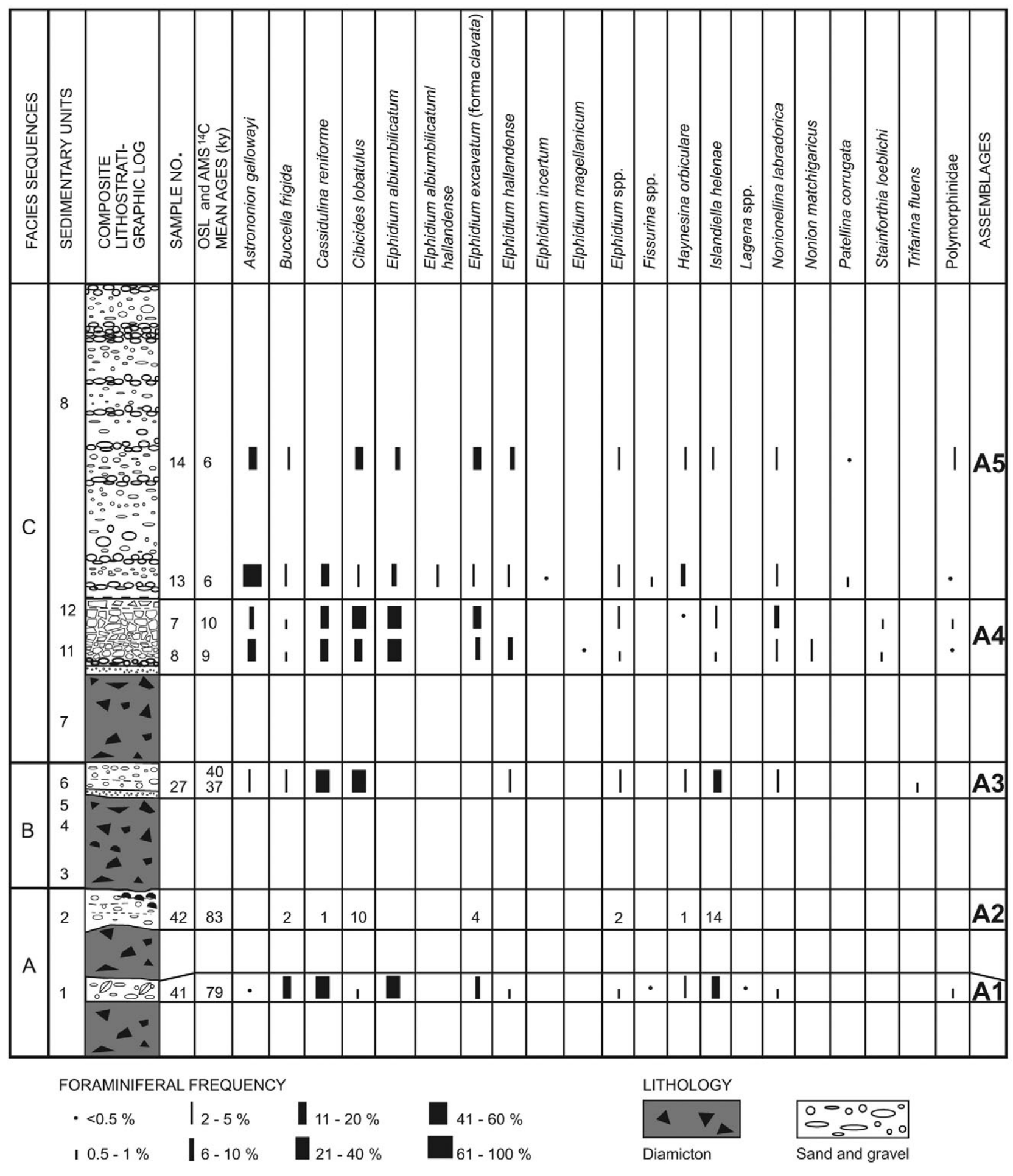

Fig. 3 Percentage distribution of benthic foraminifera from sections in Isvika, Nordaustlandet. Actual counts are inserted for sample 42, which was poor in specimens. A composite lithostratigraphic log is shown on the left-hand side, together with the sedimentary units and facies according to Kaakinen et al. (2009), and the subdivisions in foraminiferal assemblage zones A1-A5 are indicated on the right-hand side. 
Table 2 Stratigraphical correlation and environmental interpretation of the five foraminiferal assemblages, A1-A5, from Isvika, Murchisonfjorden.

\begin{tabular}{|c|c|c|}
\hline Assemblages & Environments & Stratigraphical correlation \\
\hline $\begin{array}{l}\text { A5 } \\
\text { Astrononion gallowayi }\end{array}$ & $\begin{array}{l}\text { Glacier-distal, inner shelf } \\
\text { Open ocean connection } \\
\text { Relatively stable environment } \\
\text { Slightly lowered salinity } \\
\text { Upwards increase in bottom-water currents }\end{array}$ & Mid-Holocene \\
\hline $\begin{array}{l}\text { A4 } \\
\text { Elphidium albiumbilicatum }\end{array}$ & $\begin{array}{l}\text { Glacier-distal, inner shelf } \\
\text { Open ocean connection } \\
\text { High-energy environment } \\
\text { Slightly lowered salinity } \\
\text { High-energy environment } \\
\text { Seasonal sea-ice cover }\end{array}$ & Early Holocene \\
\hline $\begin{array}{l}\text { A3 } \\
\text { Cibicides lobatulus-Cassidulina reniforme }\end{array}$ & $\begin{array}{l}\text { Glacier-distal, inner shelf } \\
\text { Open ocean connection } \\
\text { High-energy environment } \\
\text { Relatively stable salinity }\end{array}$ & $\begin{array}{l}\text { Middle Weichselian } \\
\text { (MIS3) }\end{array}$ \\
\hline $\begin{array}{l}\text { A2 } \\
\text { Islandiella helenae-Cibicides lobatulus }\end{array}$ & $\begin{array}{l}\text { Glacier-distal, inner shelf } \\
\text { Open ocean connection } \\
\text { High-energy environment }\end{array}$ & Early Weichselian \\
\hline $\begin{array}{l}\text { A1 } \\
\text { Cassidulina reniforme-Elphidium albiumbilicatum }\end{array}$ & $\begin{array}{l}\text { Glacier-distal, inner shelf } \\
\text { Open ocean connection } \\
\text { Relatively stable environment } \\
\text { Slightly lowered salinity } \\
\text { High foraminiferal productivity }\end{array}$ & Early Weichselian \\
\hline
\end{tabular}

Palaeoenvironment and age. Cassidulina reniforme is an Arctic indicator species (e.g., Hald \& Korsun 1997). The relatively high abundance of specimens of the genus Elphidium would indicate relatively shallow water and/or fluctuating salinity (Murray 1991, 2006), and Elphidium albiumbilicatum may be an indicator for mild sub-Arctic conditions, as well as for shallow conditions and reduced salinity (e.g., Lutze 1965; see discussion in Knudsen 1978). It does, however, also occur in open ocean conditions off north and north-west Iceland (Rytter et al. 2002; Jennings et al. 2004). Islandiella helenae is, on the other hand, a High-Arctic open-ocean species requiring stable salinity (Korsun et al. 1995; Hald \& Korsun 1997), and Cibicides lobatulus is an attached species indicating relatively strong bottom-water currents (Haynes 1973; Murray 1991, 2006; Hald \& Korsun 1997). This latter species also prefers relatively shallow but open marine environments (Hansen \& Knudsen 1995; Rytter et al. 2002). In summary, assemblage zone Al was most probably deposited in relatively open marine waters on the inner shelf during a high sea-level stand.

Kaakinen et al. (2009) interpreted the present sandy bed as a slab/layer, which had been incorporated into the glacial diamicton of sedimentary unit 1 (Figs. 2, 3), and the well-preserved foraminifera are considered to represent an in situ assemblage. The age of sedimentary unit 1 has been estimated to 93-65 Ky, i.e., Early Weichselian
(Kaakinen et al. 2009), and the marine sedimentary unit is considered to represent an interval of high sea-level stand.

\section{Assemblage zone A2: Islandiella helenae- Cibicides lobatulus assemblage (sample 42)}

Description. The sediment consists of bimodal pebblerich, very coarse stratified sand with some shell fragments (unit 2; Figs. 2, 3). The assemblage, which is poor in foraminifera, is dominated by large specimens of Islandiella helenae and Cibicides lobatulus, together with Elphidium excavatum f. clavata. Accessory species are Elphidium spp., Buccella frigida and Haynesina orbiculare.

Palaeoenvironment and age. The dominance of large robust specimens in this fauna presumably indicates that it represents a residual fauna, in which the smaller specimens have been dissolved or mechanically damaged, and the fine particles have been washed out. Another possibility is that the specimens have been redeposited into this unit from an older deposit. Islandiella helenae and Cibicides lobatulus both indicate open-ocean and glacierdistal environments, and additionally, Cibicides lobatulus is a high-energy indicator. Buccella frigida is often found together with Cibicides lobatulus in glacier-distal environments with relatively stable salinity (Haynes 1973), and it 
is often related to sandy sediments (e.g., Hansen $\delta$ Knudsen 1995; Hald \& Korsun 1997). It is difficult to interpret a residual assemblage, but there is some indication of a glacier-distal, high-energy environment for assemblage zone A2. The interpretation of a lag deposit for this zone is supported by the sedimentological indication of an upper shoreface to foreshore environment of unit 2 (Kaakinen et al. 2009). The age of this unit has been estimated to $93-73 \mathrm{Ky}$, i.e., Early Weichselian (Kaakinen et al. 2009).

\section{Assemblage zone A3: Cibicides lobatulus- Cassidulina reniforme assemblage (sample 27)}

Description. The sediment consists of well to moderately sorted very coarse sand and granules, as well as thin pebble beds with sharp bases and occasional cobble horizons (unit 6; Figs. 2, 3). The assemblage has a faunal diversity of 8 and is dominated by Cibicides lobatulus and Cassidulina reniforme, followed by Elphidium excavatum $\mathrm{f}$. clavata and Islandiella helenae, as well as several other accessory species. It differs from assemblage zone Al by a decrease in the percentage of Buccella frigida, and by an increase in Cibicides lobatulus, as well as in most of the accessory species (Fig. 3).

Palaeoenvironment and age. The dominance of the two species Cibicides lobatulus and Cassidulina reniforme in this assemblage indicates deposition in an Arctic, relatively shallow environment with strong bottom-water currents. Both Cibicides lobatulus and Islandiella helenae indicate glacier-distal conditions, whereas the influence of the opportunistic Elphidium excavatum $\mathrm{f}$. clavata would be an indication of less stable environmental conditions (see Hald et al. 1994). Astrononion gallowayi often occurs together with Cibicides lobatulus in areas with strong bottom currents and stable salinity (Hald \& Korsun 1997; Rytter et al. 2002). Assemblages dominated by Cibicides lobatulus are recorded in high-energy environments in the fjords of Svalbard, often related to shallow thresholds across the fjords (Hald \& Korsun 1997, Elverhøi et al. 1980), and in fjord and inner shelf areas of eastern Greenland (Jennings \& Helgadóttir 1994)

In summary, the environmental indication of assemblage zone A3 is rather close to that of assemblage zone Al, although with relatively stronger bottom currents. The faunal indication of a high energy level at the sea floor is in agreement with the interpretation of upper shoreface to littoral gravels with beach deposits for sedimentary unit 6 (Kaakinen et al. 2009). Ages of 37.0 and
40.0 Ky were obtained, i.e., a Middle Weichselian age (MIS 3) (Kaakinen et al. 2009).

\section{Assemblage zone A4: Elphidium albiumbilicatum assemblage (samples 8 and 7)}

Description. Sample 8 was collected from a sandy pebble gravel bed with shell fragments, which grades upward into shingle gravel (unit 11). Sample 7 was obtained from a clast-supported diamicton bed with a fine sand matrix containing shell fragments (unit 12; Figs. 2, 3). Elphidium albiumbilicatum and Cibicides lobatulus are the dominant species, there are high abundances of Astrononion gallowayi, Cassidulina reniforme and Elphidium excavatum f. clavata, and several accessory species occur. The faunal diversity is 8 in the lower sample and 6 in the upper sample. Compared with the underlying marine beds, this assemblage is particularly characterized by the pronounced increase in Astrononion gallowayi and Elphidium albiumbilicatum, and Nonionellina labradorica is more frequent than has been previously seen. The occurrence of Stainforthia loeblichi is unique for assemblage A4.

Palaeoenvironment and age. The strong influence of Cassidulina reniforme, Elphidium excavatum f. clavata and Buccella frigida, together with Cibicides lobatulus and Elphidium hallandense indicate Arctic, shallow-water conditions and relatively strong bottom currents. The disappearance of Elphidium hallandense, which prefers a silty and sandy sea floor (Hansen \& Knudsen 1995), in sample 7 may be a result of relatively high current velocity, as also indicated by the coarsening of the sediment towards the top of the unit (Fig. 3). This idea is supported by the appearance of Cibicides lobatulus in sample 8 . The presence of species such as Nonionellina labradorica and Astrononion gallowayi indicates a relatively stable salinity in a glacier-distal environment (e.g., Korsun et al. 1995; Hald \& Korsun 1997), whereas Stainforthia loeblichi is considered to be an indicator of seasonal ice cover in the area (Steinsund 1994).

The environmental indication of assemblage A4 supports the interpretation by Kaakinen et al. (2009) of a foreshore zone for the sedimentary environment of sample 8 (unit 11). Their interpretation of unit 12 as representing a debris flow cannot be confirmed from the assemblage. If it represents a re-deposited fauna, as suggested by the age determination, it could originate from a marine environment similar to that of sample 8. Samples 8 and 7 gave ages of 9.7 and $10.6 \mathrm{Ky}$, respectively, i.e., an early Holocene age (Kaakinen et al. 2009). 


\section{Assemblage zone A5: Astrononion gallowayi assemblage (samples 13 and 14)}

Description. The sediment consists of a coarseningupward sequence of horizontally layered sand and gravel beds with frequently occurring shell fragments of Hiatella arctica, Astarte montagui, Astarte borealis and Mya truncata (unit 8; Figs. 2, 3). Sample 13 was collected from the lower $30 \mathrm{~cm}$ of the sedimentary unit, and sample 14 was from the middle part. Astrononion gallowayi is the dominant species in both samples, and the most common accessory species are Cassidulina reniforme (sample 13 only), Cibicides lobatulus, Elphidium albiumbilicatum, Elphidium hallandense, Elphidium excavatum f. clavata and Haynesina orbiculare. Compared with the underlying marine units, assemblage zone A5 is particularly characterized by its high content of Astrononion gallowayi, by the absence of Islandiella helenae in the lower sample and by a faunal diversity of 10 , which is the highest in the entire record.

Palaeoenvironment and age. The dominance of Astrononion gallowayi, particularly in the lower sample, combined with a relatively high faunal diversity, indicates a relatively stable salinity and a connection to the open ocean during deposition. As already mentioned, this species often occurs in association with Cibicides lobatulus in high-energy, open-ocean shelf areas, and observations of high occurrences of Astrononion gallowayi, together with Cibicides lobatulus and Elphidium albiumbilicatum, have been reported by Rytter et al. (2002) from near coastal waters in Iceland. The increase in abundance of the shallow-water species Elphidium excavatum f. clavata and Elphidium hallandense, together with Cibicides lobatulus, towards the top of the section coincides with the coarsening upward of the sediments (see Kaakinen et al. 2009), presumably reflecting an increase in the bottom current speed and a gradual lowering of the relative sea level as a result of isostatic rebound. The environmental indication of the assemblage of sample 14 is not much different from that of sample 13, but it might reflect a slight shallowing in water depth. This is in agreement with the interpretation by Kaakinen et al. (2009) that this unit was deposited in upper shoreface and littoral environments, possibly during a falling sea level caused by isostatic rebound. Samples 13 and 14 have been dated at 6.4 and $6.0 \mathrm{Ky}$, respectively, i.e., mid-Holocene (Kaakinen et al. 2009).

\section{Correlation and discussion}

The foraminiferal assemblages in the Quaternary deposits from Nordaustlandet are characterized by the dominance of Arctic taxa, but there is a varying influence of a few sub-Arctic species that may indicate temporary influence of slightly warmer water conditions in the area. Generally, there is a high degree of similarity between the foraminiferal assemblage zones Al-A5 from Murchisonfjorden and assemblages described from similar stratigraphic levels in other areas of Svalbard. Some variation can be expected, however, partly because of the poor preservation state of our assemblages and our unusual laboratory preparation techniques (see above), and partly because of the influence of different local environmental factors. Thus, the number of species and specimens in the assemblages from Nordaustlandet is lower than seen at most other sites from the region. This may be an indication of less favourable conditions in Nordaustlandet than at the other sites, for instance caused by the relatively high influence of strong currents and/or occasional freshwater inflow from glaciers, but it may also be a result of the poor preservation state of the samples from Nordaustlandet. However, glacier-proximal conditions, as characterized by a total dominance of either Elphidium excavatum f. clavata and/or Cassidulina reniforme (see Nagy 1965; Hansen \& Knudsen 1995; Korsun etal. 1995; Korsun \& Hald 2000), are not reflected by any of the assemblages from Nordaustlandet.

The correlation of assemblage zones Al-A5 at Isvika, Nordaustlandet, together with other foraminiferal assemblage zones from different sites in Svalbard, are summarized in Table 3. The following correlations are mainly focused on Late Quaternary onshore sites in Svalbard.

\section{Assemblage zones A1 and A2}

Assemblage zones Al and A2 are both referred to the Early Weichselian. The depositional processes that formed the specimen-poor assemblage zone A2 are comparable with those responsible for the formation of modern residual assemblages in lag deposits in the Barents Sea (Østby \& Nagy 1981). A comparison with other Quaternary assemblages is difficult for this kind of assemblage, and the following correlation is therefore concentrated on the foraminifera-rich assemblage zone Al. Generally, the age determinations of Early Weichselian deposits are not accurate enough to distinguish between different parts of the interval, and a correlation with assemblage zone Al would therefore also include assemblage zone A2.

Shallow marine assemblages from the Poolepynten site (Fig. 1; Table 3) on Prins Karls Forland (Unit A and Unit C; Bergsten et al. 1998) contain a similar type of species composition as found in assemblage zone $\mathrm{Al}$ in Isvika. Unit $\mathrm{A}$ is characterized by a dominance of Cassidulina 
Table 3 Correlation of the assemblage zones A1-A5 from Isvika, Nordaustlandet, with previously described foraminiferal assemblages from onshore sections and raised shoreline beach deposits in Svalbard.

\begin{tabular}{|c|c|c|c|c|}
\hline $\begin{array}{l}\text { Isvika, assemblage } \\
\text { zone (this study) }\end{array}$ & Chrono stratigraphy & Locality & $\begin{array}{l}\text { Foraminiferal zone/ } \\
\text { sedimentary unit }\end{array}$ & Author \\
\hline A5 & Mid-Holocene & $\begin{array}{l}\text { Kapp Wijk } \\
\text { Talavera }\end{array}$ & $\begin{array}{l}\text { All samples } \\
\text { All samples }\end{array}$ & $\begin{array}{l}\text { Feyling-Hanssen } 1955 \\
\text { Feyling-Hanssen } 1965\end{array}$ \\
\hline A4 & Late Weichselian/Early Holocene & $\begin{array}{l}\text { Skilvika } \\
\text { Linnéelva } \\
\text { Sarsbukta } \\
\text { Guldalen } \\
\text { Visdalen } \\
\text { Blåfjorddalen }\end{array}$ & $\begin{array}{l}\text { Zone FS-IV } \\
\text { Zone FL-V } \\
\text { Zone QC } \\
\text { Entire record } \\
\text { Entire record } \\
\text { Entire record }\end{array}$ & $\begin{array}{l}\text { Lycke et al. } 1992 \\
\text { Lycke et al. } 1992 \\
\text { Feyling-Hanssen \& Ulleberg } 1984 \\
\text { Hansen \& Knudsen } 1995 \\
\text { Nagy } 1984 \\
\text { Landvik et al. } 1992\end{array}$ \\
\hline A3 & Middle Weichselian (MIS 3) & ? Wijdefjorden Region & ? Horizon 1 & Sharin et al. 2007 \\
\hline $\mathrm{A} 1$ and $\mathrm{A} 2$ & Early Weichselian (MIS 5a-5c) & $\begin{array}{l}\text { Kongsfjordhallet } \\
\text { Poolepynten } \\
\text { Skilvika } \\
\text { Linnéelva } \\
\text { Brøggerhalvøya }\end{array}$ & $\begin{array}{l}\text { Zone 1304-H; } \\
\text { Succession A } \\
\text { Unit A, upper part; Unit C } \\
\text { Zones FS-I-FS-II } \\
\text { Zone FL-IV } \\
\text { Zones F15 IV-F15 I; Episode B }\end{array}$ & $\begin{array}{l}\text { Sivertsen 1996; } \\
\text { Houmark-Nielsen \& Funder } 1999 \\
\text { Bergsten et al. } 1998 \\
\text { Lycke et al. } 1992 \\
\text { Lycke et al. } 1992 \\
\text { Miller et al. } 1989\end{array}$ \\
\hline$?$ & Eemian (MIS 5e) & $\begin{array}{l}\text { Poolepynten } \\
\text { Sarsbukta } \\
\text { Linnéelva }\end{array}$ & $\begin{array}{l}\text { Unit A, lower part } \\
\text { Zone QB } \\
\text { Zones FL-I-FL-III }\end{array}$ & $\begin{array}{l}\text { Bergsten et al. } 1998 \\
\text { Feyling-Hanssen \& Ulleberg } 1984 \\
\text { Lycke et al. } 1992\end{array}$ \\
\hline
\end{tabular}

reniforme, with Astrononion gallowayi and Elphidium excavatum as the most common accessory species. Astrononion gallowayi is particularly abundant in the lower part of Unit A, which is also characterized by a high faunal diversity. On the basis of the assemblage characteristics, and supported by amino acid dating, this part of the unit is considered to be Eemian in age (Bergsten et al. 1998), whereas the upper part of Unit A and Unit B are referred to the Early Weichselian. At the transition to unit B, there is an increase in Elphidium albiumbilicatum and Buccella frigida, and the composition of this unit is rather close to assemblage zone Al at Isvika, although Elphidium albiumbilicatum is relatively more abundant in assemblage zone Al.

The inferred ages for units $\mathrm{A}$ and $\mathrm{C}$ are $80 \pm 10$ and $70 \pm 10 \mathrm{Ky}$ at Prins Karls Forland, respectively (Bergsten et al. 1998), corresponding to the ages obtained for assemblage zone Al from Isvika (mean age $79 \mathrm{Ky}$ ). It has turned out, however, that OSL ages are often underestimated by 10-14\% (Murray \& Funder 2003; Murray et al. 2007), and sometimes by even up to 30-50\% (Larsen et al. 2009), and thus there is a possibility that the OSL ages obtained for the assemblage zones at Isvika may be too young.

Assemblage zones Al and A2 correspond in time to zones FS-I and FS-II at Skilvika, at the mouth of Bellsund (Lycke et al. 1992) (Fig. 1), and they may also correspond to assemblage zone FL-IV from Linnéelva, near the mouth of Isfjorden, western Spitsbergen (Lycke et al. 1992). These assemblages are dominated by Cassidulina reniforme, Elphidium excavatum and Astrononion gallowayi, but the species Astrononion gallowayi is relatively more frequent, and Islandiella helenae and Elphidium albiumbilicatum are less frequent at Skilvika and Linnéelva than in assemblage Al at Isvika. The overall environmental indication at these sites is, however, much alike, i.e., relatively shallow, open marine conditions with some influence of low-salinity waters, and maybe slightly ameliorated temperature conditions. Thermoluminescence datings from Skilvika gave ages of 89-105 Ky. Dating results of 87 and 118 Ky B.P. at Linnéelva may indicate a possible Eemian age for that deposit.

Foraminiferal assemblages in zones F15 IV-F15 I from Brøggerhalvøya (Miller et al. 1989), further north in western Spitsbergen (Fig. 1), may correspond in time with assemblage zones Al and A2 in Isvika. The general compositions of the assemblages are similar, but a detailed correlation is not possible because of the difference in preservation state, presumably combined with slightly different local environments (see above). The age determination for assemblage zones F15 IV-F15 I (Episode B) from Brøggerhalvøya was $70 \pm 10 \mathrm{Ky} \mathrm{B.P.,}$ and the deposits are referred to the late part of MIS 5.

A foraminiferal assemblage found in Early Weichselian deposits from Kongsfjordhallet on the opposite side of Kongsfjorden (Fig. 1), with non-finite ${ }^{14} \mathrm{C}$ ages and luminescence ages of $75 \pm 10$ and $91 \pm 9 \mathrm{Ky}$ (Sivertsen 1996; Houmark-Nielsen \& Funder 1999), is remarkably similar to those described in assemblage zone Al at Isvika. 


\section{Assemblage zone 3}

Assemblage zone A3, which is dated to the Middle Weichselian, may correspond in time to Horizon 1 described by Sharin et al. (2007) from the Wijdefjorden region in Spitsbergen (Fig. 1; Table 3). The assemblage in Horizon 1 is composed of small tests of only 10 species, dominated by the opportunistic species Elphidium excavatum, and the horizon appears to have been deposited under unfavourable environmental conditions. Unfortunately, Sharin et al. (2007) do not provide any information on the detailed faunal composition, and the correlation of Horizon 1 with the Middle Weichselian Kapp Ekholm Interstadial (Mangerud \& Svendsen 1992) is based solely on the fact that it is stratigraphically situated below the Holocene.

The probably Middle Weichselian assemblage from the Wijdefjorden region (Sharin et al. 2007), which lacks a proper age control because the age is inferred only on the basis of its relative stratigraphical position, is the only previously published description of foraminifera from onshore records in Svalbard referred to that time interval. The present description of assemblage zone A3, with well-constrained OSL and AMS ${ }^{14} \mathrm{C}$ age determinations, is thus the first description of a well-dated Middle Weichselian assemblage in the area.

\section{Assemblage zone 4}

Assemblage zone A4 is early Holocene in age and was deposited shortly after deglaciation. The assemblage is comparable with the Late Weichselian and early Holocene zone QC, as described by Feyling-Hanssen \& Ulleberg (1984) from Sarsbukta, Spitsbergen (Fig. 1; Table 3). There is also a high degree of similarity to the Late Weichselian and early Holocene assemblages in zone FS-IV from Skilvika in Bellsund (Lycke et al. 1992), whereas the underlying zone FS-III from Skilvika represents a glacier-proximal assemblage with total dominance by Elphidium excavatum f. clavata. Similar glaciomarine deposits are also found in zone FL-V at Linnéelva. All these zones are Late Weichselian to early Holocene in age.

There is a close resemblance between assemblage zone A4 at Isvika and the foraminiferal species composition in zones G7A, G7B, G7C, G5A and G5B from Guldalen, Edgeøya (Hansen \& Knudsen 1995), and part of the marine sequence at Visdalen, Edgeøya (Nagy 1984). Other foraminiferal zones from Guldalen and Visdalen, as well as those from Blåfjorddalen, Edgeøya (Landvik et al. 1992), contain different species compositions because of local differences in the palaeoenvironments.

The palaoenvironmental indications of assemblage zone A4 (Table 2) is in agreement with the findings of
Mytilus edulis, a species that has been linked with ameliorated temperature conditions and slightly reduced salinity in early Holocene deposits in the Murchisonfjorden area (Blake 2006).

\section{Assemblage zone 5}

Assemblage zone A5 at Isvika corresponds in time to some rather diverse Holocene assemblages from Talavera, which indicate ameliorated temperature conditions, and were referred to the Holocene Warm Interval by Feyling-Hanssen (1965). The environmental indication of the Isvika assemblages is considerably less favourable than for the Talavera assemblages, presumably because of the influence of relatively colder water masses in the Isvika area. The high abundance of Astrononion gallowayi at both sites is particularly remarkable. As also pointed out by Bergsten et al. (1998), similar high abundances as found in the Holocene are not yet seen in modern foraminiferal faunas. Another less diverse mid-Holocene fauna has been presented from shore terraces at Kapp Wijk in Isfjorden by Feyling-Hanssen (1955a), but at that site, the species Astrononion gallowayi was not mentioned.

The species composition in assemblage zone A5 is rather close to that in zone QC from Sarsbukta, which is rich in Astrononion gallowayi (Feyling-Hanssen \& Ulleberg 1984), even though zone QC is Late Weichselian/early Holocene in age. It is interesting to note that assemblages from onshore records of Svalbard, which are referred to the Eemian Interglacial, are often characterized by a high abundance of Astrononion gallowayi. This is, for instance, seen for the lower part of Unit A at Poolepynten (Bergsten et al. 1998), zone QB at Sarsbukta (Feyling-Hanssen \& Ulleberg 1984) and zones FL-1-FL-3 at Linnéelva (Lycke et al. 1992).

It is notable that only a few mid-Holocene marine deposits have been reported from onshore sections of Svalbard. Data from raised shoreline and beach deposits with Mytilus edulis, indicating deposition during the Holocene thermal optimum, are, however, reported from several sites by Feyling-Hanssen (1955b), Hjort et al. (1995), Salvigsen (2002) and Blake (2006), among others.

\section{Sea level and glaciations}

The timing and palaeoenvironmental interpretations for assemblage zones A1-A5 (Table 2) from Nordaustlandet are compared with the eustatic sea-level curve by Waelbroeck et al. (2002), and with the time-distance curve for the glaciations in Svalbard by Svendsen et al. (2004). Although the exact timing of the onset and termination of Weichselian glaciations in the area is not well 


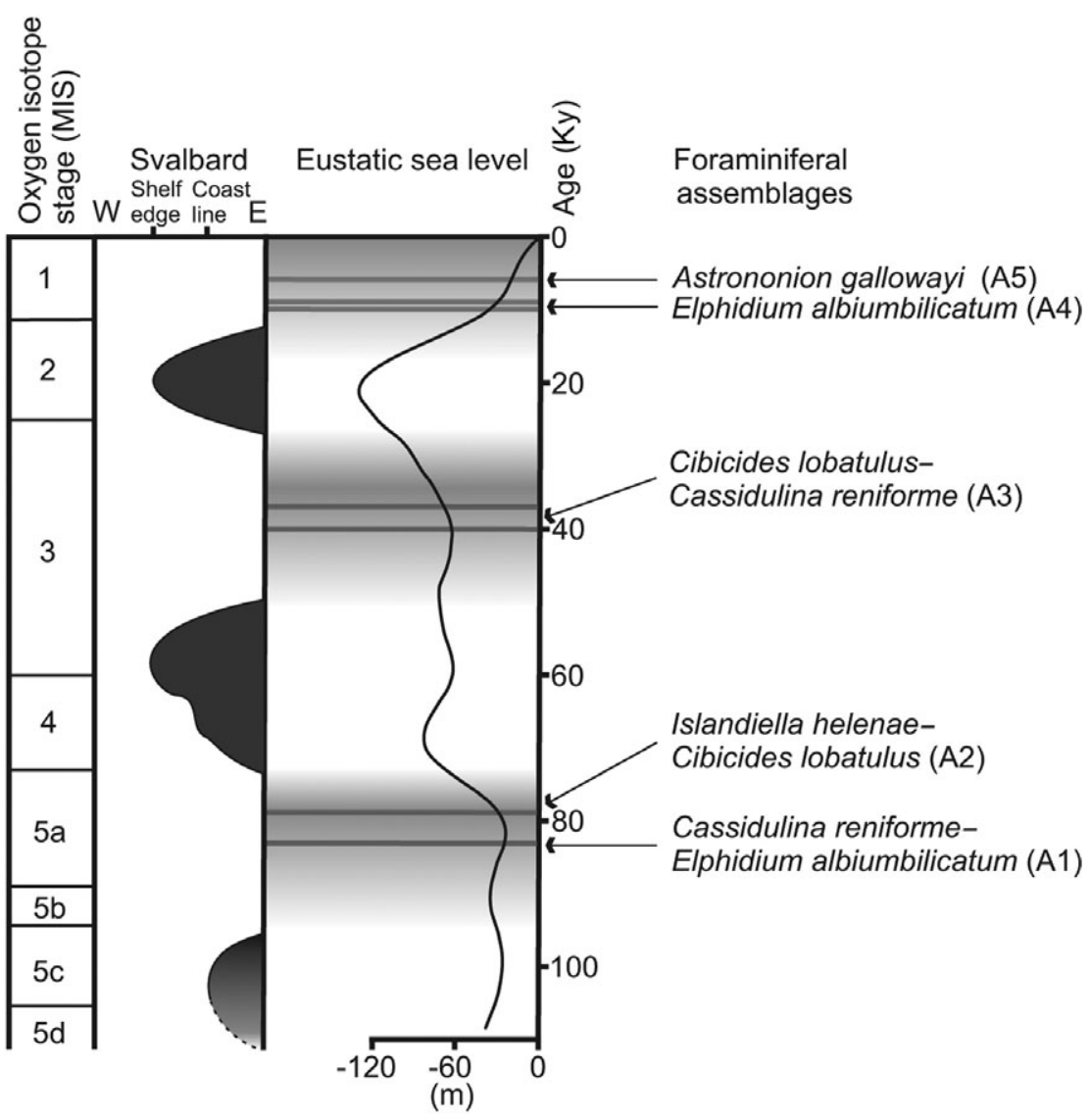

Fig. 4 Correlation of the Late Quaternary foraminiferal assemblage zones A1-A5 on Nordaustlandet with the eustatic sea-level curve of Waelbroeck et al. (2002), the timedistance curve of the western Barents Sea Ice Sheet in its northern extension over Svalbard (Svendsen et al. 2004) and marine isotope stages (MIS 5-1). Grey shading indicates the marine intervals in Murchisonfjorden (transitions are graded because the exact timing of the onset and termination of glaciations in the area is not well established). Horizontal grey lines mark the optically stimulated luminescence and accelerator mass spectrometry ${ }^{14} \mathrm{C}$ mean ages (Ky) of marine samples. determined, the marine intervals clearly correlate with periods of high global sea-level stand during interstadial/ interglacial conditions (Fig. 4).

Koç et al. (2002) state that Hinlopenstretet was covered by a grounded glacier allowing no water exchange through the strait during the Late Weichselian. The sea level was around $120 \mathrm{~m}$ lower during that time than at present (Fig. 4; Waelbroeck et al. 2002). According to Blake (2006), marine waters first entered Murchisonfjorden at the Younger Dryas-Holocene transition. This corresponds in time to the first indication of relatively warm Atlantic Water inflow into Hinlopenstretet

from the north (see Koç et al. 2002; Ślubowska et al. 2005; Ślubowska-Woldengen et al. 2007). This inflow, combined with the increase in insolation (see Ślubowska et al. 2005), probably resulted in increased melting of the glaciers on Nordaustlandet, and a subsequent large meltwater run-off into the shallow Murchisonfjorden, as indicated by the foraminiferal assemblage A4 as well as the occurrence of Mytilus edulis in the deposits.

\section{Conclusions}

This study shows that the coastal area of the northwestern part of Nordaustlandet, Svalbard, was inundated by the sea (ice free) during at least three, presumably relatively short, intervals of the Weichselian, as well as during a major part of the Holocene.

The five Late Quaternary foraminiferal assemblage zones Al-A5 from Murchisonfjorden, Nordaustlandet, all represent glacier-distal, inner-shelf environments with connection to the open ocean, but with some differences in bottom-current velocity and in salinity (Table 2).

The few foraminiferal samples in the present material gave a general overview of the environment for each assemblage zone, but changes within each zone could not be determined, except for the Holocene. It has not been possible to pinpoint the exact timing of the samples within each marine interval of the Weichselian, but they most likely derive from the middle or late stages of the interstadials.

Because of high abundances of Arctic species throughout the Late Quaternary in Svalbard, it is difficult to 
determine if sediments were deposited during an interglacial or an interstadial.

A comparison of assemblage zones Al-A5 from Isvika with previously described onshore sections and raised shoreline deposits from the Weichselian and the Holocene shows that there are some important characteristic features for the assemblages in each of the stratigraphic intervals in the area, but also that there are considerable variations as a result of the influence of different local environmental factors. The marine intervals in Nordaustlandet (assemblage zones Al-A5) clearly correlate with periods of high global sea-level stand during interstadial/interglacial conditions.

\section{Acknowledgements}

Our thanks go to Dorthe Reng Erbs-Hansen for assistance with the foraminiferal determinations, to Neil Rees for improving the language of the paper and to Weston Blake $\mathrm{Jr}$ for reading and commenting on earlier versions of the manuscript, and for improving the language. We are grateful to the journal's subject editor and to the two reviewers for valuable comments and corrections to the manuscript. This study was financed by the Academy of Finland (project no. 1116709 ), and is a contribution to the multidisciplinary International Polar Year (IPY) activity entitled IPY-Kinnvika (IPY 2007-08 project no. 58).

\section{References}

Andersen E.S., Dokken T.M., Elverhøi A., Solheim A. \& Fossen I. 1996. Late Quaternary sedimentation and glacial history of the western Svalbard continental margin. Marine Geology 133, 123-156.

Bergsten H., Andersson T. \& Ingólfsson Ó. 1998. Foraminiferal stratigraphy of raised marine deposits, representing isotope stage 5, Prins Karls Forland, western Svalbard. Polar Research 17, 81-91.

Blake W. Jr. 1961. Radiocarbon dating of raised beaches in Nordaustlandet, Spitsbergen. In G.O. Raasch (ed.): The geology of the Arctic. Pp. 133-145. Toronto: University of Toronto Press.

Blake W. Jr. 1962. Geomorphology and glacial geology in Nordaustlandet, Spitsbergen. PhD thesis, Department of Geology, Ohio State University.

Blake W. Jr. 1981. Glacial history of Svalbard and the problem of the Barents Shelf ice sheet: comments. Boreas 10, 125-131.

Blake W. Jr. 2006. Occurrence of the Mytilus edulis complex on Nordaustlandet, Svalbard: radiocarbon ages and climatic implications. Polar Research 25, 123-137.

Donner J.J. \& West R.G. 1957. The Quaternary geology of Brageneset, Nordaustlandet, Spitsbergen. Norsk Polarinstitutt Skrifter 109. Oslo. Norwegian Polar Institute.
Donner J.J. \& West R.G. 1995. Fluctuations of the Vestfonna Ice Margin at Brageneset, Nordaustlandet, Svalbard, after the Last Glacial Maximum. Bulletin of the Geological Society Finland 67, 29-36.

Ellis B.F. \& Messina A. 1949. Catalogue of foraminifera. With supplements up to 2007. New York: American Museum of Natural History/Micropaleontology Press.

Elverhøi A., Liestøl O. \& Nagy J. 1980. Glacial erosion, sedimentation and microfauna in the inner part of Kongsfjord, Spitsbergen. In: Geological and geophysical research in Svalbard and on Jan Mayen, 1980. Norsk Polarinstitutt Skrifter 172. Pp. 33-61. Oslo: Norwegian Polar Institute.

Feyling-Hanssen R.W. 1955a. Late Pleistocene deposits at Kapp Wijk, Vestspitsbergen. Norsk Polarinstitutt Skrifter 108. Oslo: Norwegian Polar Institute.

Feyling-Hanssen R.W. 1955b. Stratigraphy of the marine Late-Pleistocene of Billefjorden, Vestspitsbergen. Norsk Polarinstitutt Skrifter 107. Oslo: Norwegian Polar Institute.

Feyling-Hanssen R.W. 1965. Shoreline displacement in central Vestspitsbergen and a marine section from the Holocene of Talavera on Barentsøya in Spitsbergen. Norsk Polarinstitutt Meddelelser 93. Oslo: Norwegian Polar Institute.

Feyling-Hanssen R.W. 1972. The foraminifer Elphidium excavatum (Terquem) and its variant forms. Micropaleontology 18, 337-354.

Feyling-Hanssen R.W., Jørgensen J.A., Knudsen K.L. \& Lykke-Andersen A.-L. 1971. Late Quaternary foraminifera from Vendsyssel, Denmark, and Sandnes, Norway. Bulletin of the Geological Society of Denmark 21, 67-367.

Feyling-Hanssen R.W. \& Ulleberg K. 1984. A TertiaryQuaternary section at Sarsbukta, Spitsbergen, Svalbard and its foraminifera. Polar Research 2, 77-106.

Hald M., Ebbesen H., Forwick M., Godtliebsen F., Khomenko L., Korsun S., Olsen L.R. \& Vorren T.O. 2004. Holocene paleoceanography and glacial history of the west Spitsbergen area, Euro-Arctic margin. Quaternary Science Reviews 23, 2075-2088.

Hald M. \& Korsun S. 1997. Distribution of modern benthic foraminifera from fjords of Svalbard, European Arctic. Journal of Foraminiferal Research 27, 101-122.

Hald M. \& Korsun S. 2008. The 8200 cal. yr BP event reflected in the Arctic fjord, Van Mijenfjorden, Svalbard. The Holocene 18, 981-990.

Hald M., Steinsund P.I., Dokken T., Korsun S., Polyak L. \& Aspeli R. 1994. Recent and late Quaternary distribution of Elphidium excavatum forma clavata in Arctic seas. Cushman Foundation Special Publication 32, 141-153.

Hansen A. \& Knudsen K.L. 1995. Recent foraminiferal distribution in Freemansundet and Early Holocene stratigraphy on Edgeøya, Svalbard. Polar Research 14, 215-238.

Haynes J.R. 1973. Cardigan Bay recent foraminifera. Bulletin of the British Museum (Natural History) Zoology, Supplement 4. London: British Museum.

Hjort C., Mangerud J., Adrielsson L., Bondevik S., Landvik J.Y. \& Salvigsen O. 1995. Radiocarbon dated common 
mussels Mytilus edulis from eastern Svalbard and the Holocene marine climatic optimum. Polar Research 14, 239-243.

Houmark-Nielsen M. \& Funder S. 1999. Pleistocene stratigraphy of Kongsfjordhallet, Spitsbergen, Svalbard. Polar Research 18, 39-49.

Hyvärinen H. 1969. Trullvatnet: a Flandrian stratigraphical site near Murchisonfjorden Nordaustlandet, Spitsbergen. Geografiska Annaler Series A 51, 42-45.

Hyvärinen H. 1970. Flandrian pollen diagrams from Svalbard. Geografiska Annaler, Series A 52, 213-222.

Ingólfsson Ó., Røngvaldsson F., Bergsten H., Hedenäs L., Lemdahl G., Lirio J.M. \& Sejrup H.P. 1995. Late Quaternary glacial and environmental history of Kongsøya, Svalbard. Polar Research 14, 123-141.

Jennings A.E. \& Helgadóttir G. 1994. Foraminiferal assemblages from the fjords and shelf of eastern Greenland. Journal of Foraminiferal Research 24, 123-144.

Jennings A.E., Weiner N.J., Helgadóttir G. \& Andrews J.T. 2004. Modern foraminiferal faunas of the southwestern to northern Iceland shelf: oceanographic and environmental controls. Journal of Foraminiferal Research 34, 180-207.

Kaakinen A., Salonen V.-P., Kubischta F., Eskola K.O. \& Oinonen M. 2009. Weichselian glacial stage in Murchisonfjorden, Nordaustlandet, Svalbard. Boreas 38, 718-729.

Knudsen K.L. 1978. Middle and Late Weichselian marine deposits at Nørre Lyngby, northern Jutland, Denmark, and their foraminiferal faunas. Danmarks Geologiske Undersøgelse Series B 112, 1-44.

Knudsen K.L. 1998. Foraminiferer i Kvartaer stratigrafi: laboratorie- og fremstillingsteknik samt udvalgte eksempler. (Foraminifera in Quaternary stratigraphy: laboratory and presentation techniques as well as selected examples.) Geologisk Tidsskrift 3, 1-25.

Koç N., Klitgaard-Kristensen D., Hasle K., Forsberg C.F. \& Solheim A. 2002. Late glacial paleoceanography of Hinlopen Strait, northern Svalbard. Polar Research 21, 307-314.

Korsun S. \& Hald M. 2000. Seasonal dynamics of benthic foraminifera in a glacially-fed fjord of Svalbard, European Arctic. Journal of Foraminiferal Research 30, 251-271.

Korsun S., Hald M., Khomenko L., Forwick M., Yoon H.-I. \& Nam S.-I. 2006. Holocene paleoceanography of an Arctic fjord of Svalbard as recorded by stable isotopes, foraminifera and macrofauna. Anuário do Instituto de Geociências-UFRJ 29, 595-596.

Korsun S., Pogodina I.A., Forman S.L. \& Lubinski D.J. 1995. Recent foraminifera in glaciomarine sediments from three Arctic fjords of Novaja Zemlja and Svalbard. Polar Research $14,15-31$.

Landvik J.Y., Hansen A., Kelly M., Salvigsen O., Slettemark Ø. \& Stubdrup O.P. 1992. The last deglaciation and glacimarine/marine sedimentation on Barentsøya and Edgeøya, eastern Svalbard. LUNDQUA Report 35, 61-83.
Larsen N.K., Krohn C.F., Kronborg C., Nielsen O.B. \& Knudsen K.L. 2009. Lithostratigraphy of the Late Saalian to Middle Weichselian Skærumhede Group in Vendsyssel, northern Denmark. Boreas 38, 762-786.

Lønne I. \& Mangerud J. 1991. An Early or Middle Weichselian sequence of proglacial, shallow marine sediments on western Svalbard. Boreas 20, 85-104.

Lutze G.F. 1965. Zur Foraminiferen-Fauna der Ostsee. (On the foraminiferal fauna of the Baltic Sea.) Meyniana 15, 75-142.

Lycke A.K., Mangerud J. \& Sejrup H.P. 1992. Late Quaternary foraminiferal stratigraphy from western Svalbard. Boreas 21, 271-288.

Majewski W., Szczuciński W. \& Zajaczkowski M. 2009. Interactions of Arctic and Atlantic water-masses and associated environmental changes during the last millennium, Hornsund (SW Svalbard). Boreas 38, 529-544.

Mangerud J., Bondevik S., Ronnert L. \& Salvigsen O. 1992. Shore displacemnt and marine limits on Edgeøya and Barentsøya, eastern Svalbard. LUNDQUA Report 35, 51-60. Mangerud J., Dokken T., Hebbeln D., Heggen B., Ingólfsson Ó., Landvik J.Y., Mejdahl V., Svendsen J.I. \& Vorren T.O. 1998. Fluctuations of the Svalbard-Barents Sea Ice Sheet during the last 150000 years. Quaternary Science Reviews 17, 11-42.

Mangerud J. \& Svendsen J.I. 1992. The last interglacialglacial period on Spitsbergen, Svalbard. Quaternary Science Reviews 11, 633-664.

Miller G.H., Sejrup H.P., Lehman S.J. \& Forman S.L. 1989. Glacial history and marine environmental change during the last interglacial-glacial cycle, western Spitsbergen, Svalbard. Boreas 18, 273-296.

Murray A.S. \& Funder S. 2003. Optically stimulated luminescence dating of a Danish Eemian coastal marine deposit: a test of accuracy. Quaternary Science Reviews 22, 1177-1183.

Murray A.S., Svendsen J.I., Mangerud J. \& Astakhov V. 2007. Testing the accuracy of quartz OSL dating using a known-age Eemian site on the river Sula, northern Russia. Quaternary Geochronology 2, 102-109.

Murray J.W. 1991. Ecology and palaeoecology of benthic foraminifera. Harlow: Longman Scientific and Technical.

Murray J.W. 2006. Ecology and application of benthic foraminifera. Cambridge: Cambridge University Press.

Nagy J. 1984. Quaternary glaciomarine deposits and foraminifera from Edgeøya, Svalbard. Boreas 13, 319-332.

Nagy J. 1965. Foraminifera in some bottom samples from shallow waters in Vestspitsbergen. Norsk Polarinstitutt Årbok 1963, 109-126.

Østby K.L. \& Nagy J. 1981. Foraminiferal distribution in the western Barents Sea, Recent and Quaternary. Polar Research 1, 53-95.

Rasmussen T.L., Thomsen E., Ślubowska M.A., Jessen S., Solheim A. \& Koç N. 2007. Paleoceanographic evolution of the SW Svalbard margin $\left(76^{\circ} \mathrm{N}\right)$ since $20000{ }^{14} \mathrm{C}$ yr BP. Quaternary Research 67, 100-114. 
Rytter F., Knudsen K.L., Seidenkrantz M.-S. \& Eiríksson J. 2002. Modern distribution of benthic foraminifera on the North Icelandic shelf and slope. Journal of Foraminiferal Research 32, 217-244.

Salvador A. 1994: International stratigraphical guide-a guide to stratigraphic classification, terminology and procedure. Boulder: Geological Society of America.

Salvigsen O. 2002. Radiocarbon-dated Mytilus edulis and Modiolus modiolus from northern Svalbard: climatic implications. Norsk Geografisk Tidsskrift 56, 56-61.

Sharin V.V., Alekseev V.V., Dymov V.A., Pogodina I.A., Bol'shiyanov D.Y. \& Gusev E.A. 2007. New data on the Late Quaternary stratigraphy and paleogeography of the Wijdefjorden region (west Spitsbergen). Doklady Earth Sciences 413, 822-824.

Sivertsen J. 1996. Pleistocxn Foraminiferstratigrafi og paleoøkologi $i$ hovede kystklinter på Kongsfjordhallet $N V$ Spitsbergen. (Pleistocene foraminiferal stratigraphy and palaeoecology in raised coastal cliffs on Kongsfjordhallet, north-west Spitsbergen.) Master's thesis, Aarhus University.

Ślubowska M.A., Koç N., Rasmussen T.L. \& Klitgaard-Kristensen D. 2005. Changes in the flow of Atlantic water into the Arctic Ocean since the last deglaciation: evidence from the northern Svalbard continental margin, $80^{\circ} \mathrm{N}$. Paleoceanography 20, PA4014, doi: 10.1029/2005PA001141.

Ślubowska-Woldengen M., Rasmussen T.L., Koç N., Klitgaard-Kristensen D., Nilsen F. \& Solheim A. 2007. Advection of Atlantic Water to the western and northern
Svalbard shelf since 17,500 cal yr BP. Quaternary Science Review 26, 463-478.

Steinsund P.I. 1994. Benthic foraminifera in surface sediments of the Barents and Kara seas: modern and late Quaternary applications. PhD thesis, University of Tromsø.

Svendsen J.I., Elverhøi A. \& Mangerud J. 1996. The retreat of the Barents Ice Sheet on the western Svalbard margin. Boreas 25, 244-256.

Svendsen J.I., Gataullin V., Mangerud J. \& Polyak L. 2004. The glacial history of the Barents and Kara Sea region. In J. Ehlers \& P.L. Gibbard (eds.): Quaternary glaciationsextent and chronology. Pp. 369-378. Amsterdam: Elsevier.

Svendsen J.I. \& Mangerud J. 1992. Paleoclimatic inferences from glacial fluctuations on Svalbard during the last 20000 years. Climate Dynamics 6, 213-220.

Waelbroeck C., Labeyrie L., Michel E., Duplessy J.C., McManus J.F., Lambeck K., Balbon E. \& Labracherie M. 2002. Sea-level and deep water temperature changes derived from benthic foraminifera isotopic records. Quaternary Science Review 21, 205-305.

Walton W.R. 1964. Recent foraminiferal ecology and paleoecology. In J. Imbrie \& N.D. Newell (eds): Approaches to paleoecology. Pp. 151-237. New York: John Wiley and Sons.

Wollenburg J.E., Kuhnt W. \& Mackensen A. 2001. Changes in Arctic Ocean paleoproductivity and hydrography during the last 145 kyr: the benthic foraminiferal record. Paleoceanography 16, 65-77. 